Damijan Guštin ${ }^{*}$

\title{
Defence of the Republic of Slovenia 1991-2004: From Individual to Collective Defence
}

\author{
IZVLEČEK \\ OBRAMBA REPUBLIKE SLOVENIJE 1991-2004: \\ OD SAMOSTOJNE V KOLEKTIVNO OBRAMBO
}

Republika Slovenija je svoj še ne docela vzpostavljen obrambni sistem po uspešni obrambi junija in julija 1991 oblikovala pod vplivom varnostne nestabilnosti južnega sosedstva, kjer je še pet let divjala vojna. Kot neodvisna država je razvijala svoj nacionalno-varnostni sistem v okolju oborožene nevtralnosti, a zželjo, da se pridruži Natu in s tem preide v sistem kolektivne obrambe. Teritorialno obrambo je razvila $v$ redno vojsko in jo 1994 preimenovala $v$ Slovensko vojsko. $V$ pogojih, ki so jih določale tako omejitve OZN (prepoved prodaje orožja) kot tudi lastne zmožnosti in razpoložljivi materialni resursi, je razvila enozvrstno vojsko, ki je temeljila na vojaški obvezi in veliki vojni sestavi, ki pa jo je postopoma zmanjševala. Leta 1993 je izbrala za strateški cilj kolektivno obrambo, in si prizadevala, da se vključi v Nato. Približevanje Natu in hkratne spremembe varnostnega okolja so narekovale stevilne reforme vojske in obrambnega sektorja. V procesu priprav na vključitev v Nato v letih od 2000 do 2004 je leta 2003 opustila naborniški sistem, Slovensko vojsko preuredila v poklicno vojsko s sestavom okoli 7600 poklicnih vojakov, podčastnikov in častnikov in maloštevilno prostovoljno rezervo kot dopolnilom.

Ključne besede: varnost, obramba, TORS, Slovenska vojska, nacionalnovarnostni sistem RS, Slovenija

\section{ABSTRACT}

Following the successful defence of the country in June and July 1991, the Republic of Slovenia developed its partly unestablished defence system in the light of the instability of the country's southern neighbourhood that continued to be ravaged by war for the next five years. As an independent country, Slovenia developed its system of national defence in the context of armed neutrality, but with a desire to join Nato and thus transition to a system of collective defence. The Territorial Defence was developed into a regular army and renamed as the Slovenian Armed Forces in 1994. In the circumstances dictated both by restrictions imposed by the UN (arms embargo) as well as the country's own capacities and available material resources, Slovenia developed a single-type army based on national service and initial large numbers that were gradually

* Research Associate, PhD, Institute of Contemporary History, Kongresni trg 1, SI-1000 Ljubljana, Slovenia, damijan.gustin@inz.si 
reduced. In 1993, the country decided to pursue collective defence as a strategic goal and initiated efforts to join Nato. As Slovenia moved closer to Nato and as the security of its immediate environment changed, numerous reforms of the Army and of the defence sector loomed. During Slovenia's preparations to join Nato from 2000 to 2004, the country abandoned its national service system in 2003 and reformed the Slovenian Armed Forces into a professional army numbering about 7600 professional soldiers, NCOs and officers, as well as an additional limited voluntary reserve force.

Key words: security, defence system, Territorial Defence of Republic of Slovenia, Slovenian Armed Forces, national security system, Republic of Slovenia

\section{Defending the Independence and the Slovenian Defence System in 1991}

As early as on the second day of its existence as an independent country, Slovenia was, on 26 June 1991, already forced to defend itself with force, as it tried to preserve its independence. The state leadership described the intervention of the Yugoslav People's Army as an act of aggression. The armed conflict with the Yugoslav People's Army was limited, of low intensity and short in duration. The Brijuni Agreement, signed a week after the cease-fire on 2 July 1991 that ended the conflict, codified the cease-fire as an institutional armistice whose observance would be monitored by the European Community. Following a decision by the Presidium of the Socialist Federal Republic of Yugoslavia on the (temporary) retreat of the Yugoslav People' Army from Slovenia on 18 July 1991, the Republic of Slovenia became a de facto independent country, despite a three-month moratorium. ${ }^{1}$ By 26 October 1991, when the last remnants of the Yugoslav People's Army's forces left the territory of the Republic of Slovenia, Slovenia was an independent, sovereign country, although as yet unrecognised by the majority of the world's countries (i.e. only recognised by 4 ) and still facing serious threats to its security.

The defence system that Slovenia established in autumn 1990 successfully stood the test of war in June 1991. However, the system of national security was developed only to the degree allowed by the situation of Slovenian secession, when the country was still intertwined with the Yugoslav system of national security, which meant that the Slovenian defence system was only able to separate itself from the unified Yugoslav system as much as the circumstances allowed. The system was based on a creative adaptation of the Yugoslav defence system and included those elements that were within the jurisdiction of the republics, which, as Yugoslavia underwent a serious crisis, were able to claim for themselves at least part of its (otherwise federal)

1 Božo Repe, Jutri je nov dan. Slovenci in razpad Jugoslavije (Ljubljana: Modrijan, 2002). Tomaž Kladnik, ed., Vojaška obramba Slovenije 1990-1991 (Ljubljana: Defensor, 2011). Tomaž Kladnik, Slovenska vojska v službi domovine (Ljubljana: Defensor, 2006) 26-32. 
powers. The defence forces thus consisted of three elements, the Territorial Defence, the People's Militia and the Civil Protection Service. ${ }^{2}$ To defend the country's independence, these forces were able to call upon 70,000 conscripts of the Territorial Defence (just prior to the start of the war, the number available was increased by a few thousand by transferring younger conscripts from the Yugoslav People's Army to the Territorial Defence), about 9,000 active and reserve members of the Militia, and the Civil Protection Service. In actuality, about 35,000 members of the Territorial Defence and 7100 members of the Militia were mobilized. ${ }^{3}$

After the cease-fire agreement was signed on 8 July 1991, armed forces were never again used to defend the country, in spite of serious threats to its safety and the outbreak of the war in neighbouring Croatia in the autumn of the same year. While the three-month moratorium on Slovenian independence which was included in the peace treaty did represent an obstacle, it did not prevent the coordination of urgent defence matters. After the Federal Presidium of the Socialist Federal Republic of Yugoslavia decided on 18 July to temporarily recall the Yugoslav People's Army's units and institutions from Slovenia, the Slovenian defence system was able to act more freely. The further development of the defence and security system of Slovenia thus proceeded in peace, even though Slovenia remained positioned at the edge of the warring Western Balkans and subject to measures of the international community pertaining to the area of the former Yugoslavia, most notably an embargo on the purchase of arms.

The first order of business was thus to build up the defence system. The strategy for the development of the Slovenian defence system oscillated between the only system possible at the time - a defence by means of own armed forces and other unarmed entities - and the emerging wishes for Slovenia to join the collective defence system represented by the North Atlantic Treaty Organization (Nato). On 6 October 1991, after more than three months, the retreat of the Yugoslav People's Army forces was finally over. By gaining its independence, the Republic of Slovenia became a rather small country, both in terms of the standard quantitative criteria as well as in terms of recognising that it could ensure its own safety only by relying on other countries and international organizations and institutions. ${ }^{4}$

\section{"The Time of Enthusiasm"5 - Development of the Security and Defence System in 1991-1993}

In autumn 1991, senior officials of the Slovenian defence structures prompted the continuation of the development of the defence system. In terms of the internal

2 Kladnik, ed., Vojaška obramba Slovenije, 14, 15.

3 Ibid., 15, 16.

4 See: Špela Kranjc, "Članstvo v NATO. Študija primerov Slovenije in Estonije” (diplomsko delo, Fakulteta za družbene vede, 2009), 9.

5 Alojz Šteiner, Slovenska vojska med tranzicijo in transformacijo (Ljubljana: Slovenian Armed Forces, Military Schools Centre, 2015), 53. 
development of the Slovenian security and defence structures, this period had started as early as prior to the country's declaration of independence on 25 June $1991 .^{6}$

Security threats to the country remained high, as war raged across neighbouring Croatia, with battles being fought immediately across the south-eastern Slovenian border until at least January 1992. In terms of Slovenian security and defence policy, the fact that the Republic of Croatia was the weaker side in its conflict with the Yugoslav People's Army and the Serbian population (of the Republic of Serbian Krajina) and at the same time a partner (ally) that irrevocably lost the trust of the Slovenian state authorities on 26 June 1991 was troubling, as it precluded any future alliances. For a while it seemed quite possible that the forces of the Yugoslav Army would reappear at the southern border. A part of Slovenian armed forces was thus assigned to protect it. This was one of the reasons why Slovenia, under an arms embargo that applied to the whole area of former Yugoslavia, began helping Croatia and later Bosnia by supplying them with arms. However, this turned into an arms trade managed by the Slovenian Ministry of Defence by summer 1991. Eventually, the competent state authorities became the immediate sellers, dealers and sometimes brokers of material, including not just what had been captured from the Yugoslav People's Army or contained in their or the Territorial Defence stockpiles, but also arms purchased on the grey market. ${ }^{7}$ However, in doing so, Slovenia generally proceeded with awareness of its own arms requirements, which the country was able to largely cover using confiscated or relinquished materiel previously used by the Yugoslav People's Army.

Using the Constitution of the Republic of Slovenia, adopted in December 1991, the country defined its defence system at the highest level, while leaving the determination of the detailed structure of its armed forces to further legislation. The Constitution expressly limited the use of force to the defence of state sovereignty and territorial integrity. The Constitution legislated parliamentary control over the Slovenian armed forces and the possibility of conscientious objection to military service. The only remaining mention of the previously well-supported demilitarized national defence was the following non-binding comment: "In the provision of security the state proceeds principally from a policy of peace, and an ethic of peace and non-aggression." ${ }^{8}$ Slovenia legislated defence using armed forces and thus provided

6 The Defence and Protection Act (Zakon o obrambi in zaščiti) was passed on 29 March 1991 and the Military Service Act (Zakon o vojaški dolžnosti) on 6 April 1991; the symbolic first contingent of recruits was also conscripted before the declaration of independence, on 15 May 1991. See: Kladnik, ed., Vojaška obramba Slovenije, 87.

7 Matej Šurc, Prevarana Slovenija. Domoljubje, zapisano z ničlami (Ljubljana: Sanje, 2016). Matej Šurc and Blaž Zgaga, Vimenu države. Trilogija: book 1: Odprodaja (Ljubljana: Sanje, 2011). Matej Šurc and Blaž Zgaga, Vimenu države. Trilogija: book 2: Preprodaja (Ljubljana: Sanje, 2011).

8 Official Gazette of the Republic of Slovenia, No. 33/1991, 28 December 1991, Constitution of the Republic of Slovenia, Article 124. The alternative pacifist idea of guaranteeing safety without an army, which was the subject of a political clash in the spring of 1991, was thus abandoned. See Anton Grizold, "Obrambni sistem republike Slovenije. Stanje in perspektive nadaljnjega razvoja," in: Zbornik strokovno znanstvenih razprav (Ljubljana: Ministry of the Interior of the Republic of Slovenia, December 1991), $161-181$. 
a basis for its concept of armed neutrality. However, both the political elite and the public were already talking about initiatives to join Nato, which was believed to be necessary to guarantee Slovenia's sovereignty in light of the wars raging nearby. ${ }^{9}$

The structure of the Territorial Defence of the Republic of Slovenia, which retained its original name in spite of efforts to change it to Slovenian Army, remained unchanged, as the Defence Act was not amended for a while either. The formation of the army initially remained the same as during the war, i.e. with 7 regional headquarters and 26 subordinate area headquarters of the Territorial Defence. The Slovenian army remained primarily territorial, but, inasmuch as it was possible under the embargo and with limited financial resources, it continued to develop branches and services it was lacking; i.e. artillery, armoured unites, the air force. Arms left in Slovenia by the Yugoslav People's Army, including about 140 tanks, were of great help in this regard. The systems and doctrines of General People's Defence and Social Self-Protection were abandoned. The creation of a new military tradition based on the new foundation of the "War for Slovenia" and the part played by Slovenian forces in the State of Slovenes, Croats and Serbs was also well under way. ${ }^{10}$

The Army was manned through general compulsory military service. ${ }^{11}$ Conscription resumed in 1992. That year, 8151 conscripts finished their training in the Territorial Defence of the Republic of Slovenia, followed by 10,000 to 12,000 annually, as those who had not served their military duty in the years when Slovenia was gaining independence were conscripted as well. The Defence Act from April 1991 already gave conscripts the right to conscientious objection and thus to serve their duty in non-military contexts. 7 conscripts exercised this right in 1992; in the following years, their numbers increased and truly balooned only after $1997 .{ }^{12}$ The seven-month training (which actually only lasted six months) during military service was of a dual nature, with one part taking place at education centres and the other in peace-time units of the Territorial Defence. The army was professionally reinforced with commissioned and non-commissioned officers of the Yugoslav People's Army, as the Territorial Defence employed virtually every officer who heeded the appeal of the Presidium of the Republic of Slovenia and defected to the Territorial Defence by 1 July 1991. Of the 1893 employees of the Territorial Defence at the end on 1991, 1278 had previously served in the Yugoslav People's Army. ${ }^{13}$

Another objective of the development was to increase the professional core of the armed forces and establish a professional military unit, the so-called $1^{\text {st }}$ Special

9 Anton, Bebler, "Pot Slovenije v Nato = Slovenia’s road to Nato," Bilten Slovenske vojske 11, No. 3 (November 2009): 107.

10 Cf. Vladimir Prebilič and Jelena Juvan, "(Ne)obstoj slovenske vojaške identitete," Sodobni vojaški izzivi 14, No. 1 (2012): 55-67.

11 At the time, the Army had at its disposal slightly over 15,000 conscripts every year. Cf. Andrej Lovšin, "Obrambni sistem in kadri od leta 1991 do 2003, 2," Slovenska vojska 12, No. 1, 16 January 2004 .

12 Ibid.

13 Marijan Kranjc, Slovenska vojaška inteligenca (Grosuplje: Grafis Trade, 2005), 408. 
Brigade MORiS, established in October 1992, that was not a part of the Territorial Defence but rather answered directly to the Ministry of Defence. The armed forces of the Territorial Defence of the Republic of Slovenia numbered 77,000, but only $5 \%$ of these were regular peacetime forces. ${ }^{14}$

Political parties were banned from the armed forces, and professional employees - primarily commissioned and non-commissioned officers - were not allowed to be party members or to partake in any party-related activities while in uniform. However, this does not mean that political influences and opinions could not be felt in the functioning of the defence system. Following the example of the countries of Western Europe, the army came under civilian control, specifically under control of the Parliament.

The army, which had won the 1991 war, enjoyed a high level of public trust, with state authorities further deliberately developing its positive public image. Citizens saw the armed forces of their country as an important and non-problematic part of the state structure and expressed a higher than average level of trust in it. ${ }^{15}$

On 3 February 1992, the Presidium of the Republic of Slovenia approved the proposed General Plan for the Organization, Outfitting, Arming and Training within the Territorial Defence of the Republic of Slovenia. According to the Plan, the Territorial Defence would have 45,000 members, 18,000 of whom would be in the manoeuvre forces, i.e. the special brigade, the missile and helicopter brigade, seven infantry brigades, four armoured and mechanized battalions, an anti-tank division and a support artillery division. The professional part of the army would consist of 1350 commissioned officers, 1550 non-commissioned officers and 1700 privates. The special brigade would be wholly professional. ${ }^{16}$ The Plan was the first complex programme that laid out a tangible strategy for the development of the Slovenian army. In the following years, the Territorial Defence attained the goals that had partly already been set and implemented when the Plan was approved.

\section{Transformation into a Classic National Army}

The years from 1993 to 1995 were a time of normative efforts to transform the Territorial Defence into a classic national army that would be able to defend Slovenian sovereignty on its own, even though the state leadership simultaneously already initiated the efforts to move closer to Nato and to eventually join it. The Resolution on the Basis for the Concept of National Security of the Republic of Slovenia was

14 Šteiner, Slovenska vojska med tranzicijo in transformacijo, 53. Grizold claims 87,000 members of the armed forces and 3000 regular employees.

15 Tomaž Repnik, "Odnos civilne družbe do Slovenske vojske v obdobju 1991-2006" (diplomsko delo, Fakulteta za družbene vede, 2006).

16 Kladnik, ed., Vojaška obramba Slovenije, 18-19. "Pomembnejši utrinki iz zgodovine Slovenske vojske od prevzema popolne suverenosti nad slovenskim ozemljem do danes - 20 let ponosni nase in $\mathrm{v}$ ponos Sloveniji," retrieved on 7 June 2016, http://www.slovenskavojska.si/fileadmin/slovenska_vojska/ pdf/sporocila/20let_zgod.pdf. 
adopted in December 1993. ${ }^{17}$ The Resolution emphasized that "[f]or the Republic of Slovenia as part of a new international reality and a country located in the immediate vicinity of the Balkans crisis area, provision of national security is a matter of primary importance." 18 The Slovenian army was defined as a defence force of the Republic of Slovenia whose aim was to deter any attacks on the country and to coordinate and implement military defence in the event of outside aggression or other forceful interventions of foreign military forces against Slovenia. The Resolution defined three primary ways in which Slovenia could be threatened: through a military attack by an outside force, through internal threats including possible attempts of a violent transformation of the social order, and through threats to the environment. Slovenian Armed Forced were in charge of military defence against a potential outside attack, while civil defence was tasked with civilian defence. Security was supposed to be ensured by a security system whose main parts were the Ministry of the Interior and two intelligence and security services. On the other hand, a system of protection and rescue was set up to protect against environmental dangers. ${ }^{19}$

Joining Nato, i.e. transitioning to collective defence, was first set as a national policy goal a year before, when it was also approved by the General Assembly. In January 1994, Nato published a call for participation in a pre-joining preliminary programme called Partnership for Peace (Partnerstvo za mir). ${ }^{20}$ At the same time, with a resolution amendment passed in January 1994, joining Nato was defined as an important objective of Slovenian national defence, even though the resolution focused primarily on political and diplomatic cooperation and only secondarily on military cooperation. ${ }^{21}$ Slovenia joined the Partnership for Peace programme as early as 30 March 1994. Next year saw the creation of the first Individual Partnership Programme, which both determined Slovenia's political objectives and stated the military and other capacities Slovenia could offer to Nato. ${ }^{22}$ This period is also characterized by high internal tensions between the security services of the Ministry of the Interior and the Ministry of Defence, with suspicions of a planned coup and with the removal from office of the Minister of Defence in March $1994 .^{23}$

New defence legislation was passed on 20 December 1994, after more than a year of discussion and coordination. 24 "The Defence Act provided a comprehensive

17 Official Gazette of the Republic of Slovenia, No. 71/1993, 30 December 1993.

18 Ibid., item 11.

19 Ibid. Cf. Anton Grizold, "Nejasen namen. Resoluciji o izhodiščih zasnove nacionalne varnosti Republike Slovenije na rob," Primorki dnevnik 49, No. 88, 1993.

20 NATO, Official texts: Partnership for Peace Invitation Document, 10-11 January 1994, retrieved on 7 October 2016, http://www.nato.int/cps/en/natohq/official_texts_24468.htm?mode=pressrelease.

21 Official Gazette of the Republic of Slovenia, No. 2/1994. David Humar, Ivan Mikuž, Samo Zanoškar, Dean Groff and Leon Holc, "Integration of the Slovenian armed forces into NATO and EU military structures," Bilten Slovenske vojske 11, No. 2 (2009): 60.

22 Ibid., 61. Šteiner, Slovenska vojska med tranzicijo in transformacijo, 78.

23 Cf. Janez Janša, Okopi. Pot slovenske države 1991-1994 (Ljubljana: Mladinska knjiga, 2014).

24 Official Gazette of the Republic of Slovenia, No. 82/94, Defence Act. Cf. Božo Repe, Milan Kučan: prvi predsednik (Ljubljana: Modrijan, 2015), 404-06. 
framework for the defence system, primarily in terms of organization, structure, tasks and other issues pertaining to the Slovenian Armed Forces as a classic military organization as well as in terms of civil defence. The Act also settled matters significant for the organization and planning of defence, which came under the sole authority of the state. The Defence Act separated the defence system from the system of protection against natural and other disasters, except in cases where the systems complemented each other." 25 Pursuant to the Act, the Territorial Defence of the Republic of Slovenia was renamed as the Slovenian Armed Forces the following year.

After the adoption of an amendment to the Military Service Act, an important change was implemented in regard to the training of conscripts. ${ }^{26}$ In September 1996, education centres were abolished and the conscripted recruits trained within military units. That way, the Slovenian Armed Forces were able to increase the numbers of their peacetime units. This was also the first time that additional funds were envisioned for arms purchases, while the so-called Basic Development Programmes were used to define the armament and equipment requirements in detail. ${ }^{27}$

In August 1995, Croatia achieved military victory with Operation Storm, thus stabilizing Slovenia's southern neighbourhood and greatly decreasing the security and military threats faced by Slovenia. ${ }^{28}$

\section{Hoping for NATO}

In late 1990s, the direction and forms of development of the national security system of the Republic of Slovenia were mostly determined by strategies for the accession of Slovenia to the European and Euro-Atlantic institutional frameworks, i.e. the European Union and Nato. In addition to Slovenia, all former members of the Warsaw Pact and the newly formed Baltic states wanted to join Nato as well; they expected the organization to involve them in its system of collective security and thus solve all their security problems, from issues regarding doctrine and development to structural matters. However, unlike the Slovenian political elite, the population continued to show significant support for the concept of armed neutrality, and the idea that the country should join Nato's system of collective defence was met with some doubts and resistance. ${ }^{29}$

In 1996, the so-called individual dialogue was used to prepare the involvement of

25 "Defence Act: draft from 13 April 2016, EVA 2016-1911-0001," retrieved on 10 October 2016, http://www.mo.gov.si/fileadmin/mo.gov.si/pageuploads/pdf/predpisi/obramba/v_pripravi/ZObrMedresorsko_20160413.pdf.

26 Official Gazette of the Republic of Slovenia, No. 94/95, Military Service Act - official consolidated text.

27 Official Gazette of the Republic of Slovenia, No. 13/94, Act Providing Funds for the Realization of Basic Development Programmes of the Armed Forces of the Republic of Slovenia in 1994-2007.

28 Jože Pirjevec, Jugoslovanske vojne: 1991-2001 (Ljubljana: Cankarjeva založba, 2003). Ozren Žunec, "Operacije Bljesak i Oluja," in: Rat u Hrvatskoj i Bosni i Hercegovini: 1991-1995, eds. Branka Magaš and Ivo(Zagreb: Jesenski i Turk and Sarajevo: Dani, 1999), 93-110.

29 Cf. Bebler, "Pot Slovenie v NATO = Slovenia’s road to NATO," 111, 112. 
Slovenian Armed Forces in the process of planning and assessment in which reforms and reorganizations of the defence system were being determined. Particular attention was paid to the issue of compatibility with old member states..$^{30}$

Among the results of the process of joining the collective defence system was the decision for Slovenia to participate in peacekeeping operations in various crisis areas all over the world. The first such intervention began in 1997, when the first 25 members of the Slovenian Armed Forces and two members of the Police were sent to participate in the ALBA peacekeeping operation in Albania. ${ }^{31}$

Slovenian request to join was turned down at the Madrid session of Nato in 1997. ${ }^{32}$ The following period of operation of the Slovenian defence system was wholly dedicated to continuing the process of accession to Nato. As the reason behind the rejection was the fact that the Slovenian army hadn't implemented the necessary reforms, the country, in order to finally and surely attain the membership, resumed political efforts and undertook a number of military reorganizations. In 1998, the country developed the National Strategy for the Accession of Slovenia to Nato. The effects of joining Nato were stated as follows: "Accession of Slovenia to Nato would improve the security of the Republic of Slovenia and contribute to the country's long-term development." 33

As part of the accession process, Slovenia effected or had to implement a number of structural reforms of its military and the defence system in general. The main principles of the reforms were determined by the Strategy of Military Defence of the Republic of Slovenia drafted in 1998. The strategy proposed a re-ordering of the armed forces into rapid reaction forces, main defence forces and auxiliary defence forces. The strategy also anticipated an increased permanent force bolstered by professional soldiers.

Another important aspect of the strategy was cooperation with allied forces. In 1998, Slovenia was also the first candidate country to host the Cooperative Adventure Exchange-98 military exercise which was also used to assess the candidate state's logistical and support capacities.

In 1999, Nato adopted the Membership Action Plan, which included Slovenia. ${ }^{34}$ This formed the basis on which Slovenia, starting in 2000, developed its annual national programme for the attainment of membership in Nato. National programmes

30 Šteiner, Slovenska vojska med tranzicijo in transformacijo, 78. Š. Kranjc, "Članstvo v NATO," $29,30$.

31 Jelena Juvan, "Mirovne operacije kot sredstvo zagotavljanja nacionalne varnosti?” (Defence Research Centre of the Faculty of Social Sciences of the University of Ljubljana), retrieved on 2 July 2016, http://www.fvv.um.si/DV2010/zbornik/nacionalna_varnost/juvan_doc.pdf. Jelena Juvan, "Slovenska vojska v mirovnih operacijah," in: Mirovne operacije in vloga Slovenije, ed. Ljubica Jelušič (Ljubljana: Faculty of Social Sciences, 2005), 175-86. Klemen Grošelj, Slovenija v svetu mirovnih operacij (Ljubljana: Založba FDV, 2007), 124-40.

32 Šteiner, Slovenska vojska med tranzicijo in transformacijo, 83.

33 "National Strategy for the Accession of the Republic of Slovenia to Nato," (February 1998), retrieved on 4 June 2016, http://nato.gov.si/slo/dokumenti/nacionalna-strategija.pdf.

34 Šteiner, Slovenska vojska med tranzicijo in transformacijo, 83. 
encompassed matters of politics and the economy, defence and the military, and of security, as well as legal and financial issues, which means that the reforms carried out in order to join the military alliance were extremely complex and also extended to areas other than defence. The reforms were carried out in dialogue with Nato's structures. The four-year period that preceded Slovenia's accession to Nato, with its four annual national programmes, was the main period of adjustment for the Slovenian Armed Forces. ${ }^{35}$ In February 2000, the General Long-Term Plan for the Development and Outfitting of the Slovenian Armed Forces (Splošni dolgoročni program razvoja in opremljanja Slovenske vojske - SDPRO SV) was adopted, further determining the organizational and technical aspects of outfitting the Slovenian Armed Forces in a ten-year period. ${ }^{36}$

\section{Adapting to NATO}

At the beginning of the new millennium, the issues of Slovenian security and defence became less acute. The conflict in the immediate Yugoslav neighbourhood had settled, and after the Croatian victory in Operation Storm and the Dayton Peace Agreement regarding Bosnia and Herzegovina, peace returned to the Western Balkans, with the exception of Kosovo. National defence became a function without a tangible goal, and security threats were minimal. ${ }^{37}$ This resulted in a diminishing focus on security and defence and in dwindling care for the defence of the country. This change of circumstances coincided with processes of modernization within Nato that were being implemented since the end of the Cold War. The central aspect of these changes was the shift of security threats from military to non-military and the resulting need to transform armed forces from high-manpower militaries to professional forces with smaller numbers. Mass armies of citizens were unsuited for new security threats, so almost all Nato member countries transitioned to professional armed forces.

From 2000 onward, Slovenia carried out the second cycle of adaptations to the Western armies in Nato. The adaptations or reforms extended to three important areas:

1. organizational changes to forces, differentiation between mobile and immobile forces;

2. separation of operational command and strategic command (including physical separation: Force Command in Vrhnika and General Staff in Ljubljana);

35 "Slovenija in NATO: kronologija slovenskega vključevanja v NATO,” Kronologija včlanjevanja, retrieved on 12 June 2016, http://nato.gov.si/slo/slovenija-nato/.

36 Official Gazette of the Republic of Slovenia, No. 32/2000, 1483, 13 April 2000.

37 According to a representative public opinion survey carried out by the Defence Research Centre in 2003 , only $14 \%$ of respondents felt threatened in any way. $42.5 \%$ of those surveyed believed that it was unlikely for Slovenia ever to need an army again. In a similar study carried out in 2001, this belief was only shared by 31 \%. - "Slovenci se počutimo varne," Slovenska vojska 12, No. 1, 16 January 2004. 
3. discontinuation of the system of conscription and establishment of a professional army.

In 2002 Slovenia was finally invited to begin accession negotiations for Nato membership. This signalled the beginning of rapid changes for the Slovenian Armed Forces: decrease of reserves to less than $50 \%$ of the previous numbers, gradual discontinuation of conscription and creation of a professional army, development of forces that could participate in the allied contingent. After a decade of decreases, the defence budget again increased to almost two percent of the GDP.

Among the most visible aspects of the reform of the Slovenian Armed Forces was the suspension of manning the forces through conscription and the establishment of a professional army. Slovenia abolished compulsory military service in 2003, a year before the country had planned to do so and a mere two years after the idea was first proposed. The last generation of conscripts to serve military duty left their barracks on 15 October 2003.38

However, adapting to Nato's standards didn't only encompass military policy documents but was also reflected in frequent military reforms that pertained to either certain segments of armed forces or to the whole military - beginning with amendments to the Defence Act that regulated the participation of the country in the system of collective defence at a normative level, stating that national defence "is also being realized through the joining and active involvement of the country in international security associations based on international treaties". The structure of forces within the army and the military intelligence and security activities were changed as well. The amendment also instituted voluntary service in the contractual reserve formation. With regard to professional soldiers, provisions regulating military service were improved and special working conditions were regulated as well. ${ }^{39}$

Pursuant to these amendments, the manpower of the Slovenian Armed Forces was decreased from 47,000 to 30,000 people. District territorial headquarters and some of the operational commands were abolished. The Force Command was established in 2003. Units of rapid response forces were given priority to be manned by professional soldiers.

The rapid and constant changes to the Slovenian Armed Forces had a negative impact as well, as various reform measures had unwanted effects. Numerous solutions were barely given a chance before being reformed again. Changes to various units and especially commands were sometimes left unfinished, be it due to material limitations or rapidly changing circumstances.

As the professional part of the armed forces had too many commissioned and non-commissioned officers and too few privates, the military mostly offered employment to the latter. Gradually the numbers of the Slovenian Armed Forces increased towards the target of 8000 . By the end of 2001, there were 5043 of them, but by the end of 2005 , the number already increased to 7316 . In the same period, the num-

38 Lovšin, "Obrambni sistem in kadri od leta 1991 do 2003, 2."

39 Official Gazette of the Republic of Slovenia, No. 47/2002, Act Amending the Defence Act. 
ber of professional soldiers increased from 707 to 2918.40 The status of soldiers as public employees was problematic as well, as it was often unsuitable for professional soldiers.

After the initial increase, when the numbers of the voluntary contractual reserves reached about 1400, replenishment of forces stagnated. In 2005, the reserves consisted of 7917 conscripts. Service in the military was voluntary and possible for both men and women, and a couple hundred volunteers took advantage of this each year. ${ }^{41}$

\section{Slovenian Armed Forces Outside Slovenia}

One of the most visible forms of operation of the Slovenian Armed Forces was their participation in so-called "crisis response operations", i.e. in missions in crisis areas. From the first such case in 1997 onward, the presence of Slovenian Armed Forces abroad as part of missions led by the UN, the European Union or Nato increased, and such cooperation became a mainstay of the army's operation. Another important part of the army's activities was its participation in missions in the area of former Yugoslavia, particularly in Bosnia and Herzegovina. In 2005, members of Slovenian Armed Forces were thus involved in six such operations, with their participation being most numerous in Bosnia, Kosovo and Afghanistan. ${ }^{42}$ As members of the Slovenian Armed Forces left for various crisis areas, their numbers increased, so did the intensity of their assignments. However, in all peacekeeping missions, members of Slovenian Armed Forces were integrated with larger units under foreign command. 43

\section{Joining Collective Defence - Objective Attained and the Beginning of a New Period}

The voices that were critical of the idea of joining Nato led the national political elite to call a referendum on this issue while simultaneously campaigning in its support. Slovenia was only the second country to decide for such a procedure. At the referendum held on 23 March 2003, joining Nato was supported by $66.08 \%$ of those who voted, and this result provided the political elite with enough support to implement the final steps of the process. ${ }^{44}$ Six days later, on 29 March 2004, Slove-

40 “Letno poročilo Ministrstva za obrambo za leto 2005. Mors, 27 May 2014," retrieved on 5 May 2016, http://www.mo.gov.si/fileadmin/mo.gov.si/pageuploads/pdf/ministrstvo/letno_porocilo_2005. pdf.

41 Ibid., 15, 16, 31. "Prvih sto prostovoljcev," Slovenska vojska, 12, No. 1, 1.

42 "Letno poročilo MORS za leto 2005," 16-18.

43 Juvan, Mirovne operacije kot sredstvo zagotavljanja nacionalne varnosti?, 175-86. Grošelj, Slovenija v svetu mirovnih operacij, 124-40.

44 "Poročilo o izidu glasovanja o izidu referenduma o pristopu Republike Slovenije k Organizaciji Severnoatlantske pogodbe (NATO), ki je bil 23. marca 2003," Referendumski rezultati, retrieved on 8 October 2016, http://nato.gov.si/slo/slovenija-nato/referendum/rezultati/. 
nia ratified the accession agreement and became a member of Nato. ${ }^{45}$ For the Slovenian defence system, this signalled the end of a difficult and sometimes contradictory journey towards becoming a part of the European defensive alliance - though on its margin - as well as a part of the ring around the crisis area of former Yugoslavia (Croatia, Bosnia and Herzegovina, Serbia, Kosovo, Montenegro, Macedonia and Albania) that now consisted of Slovenia, Hungary, Romania, Bulgaria and Greece, along with Italy across the Adriatic Sea. The security configuration in the area was thus greatly improved, although not yet completely in place, as there were already signs that the countries that were at the time still isolated would eventually be included as well.

\section{Sources and Literature}

- “Defence Act: draft from 13 April 2016, EVA 2016-1911-0001.” Retrieved on 10 October 2016. http://www.mo.gov.si/fileadmin/mo.gov.si/pageuploads/pdf/predpisi/obramba/v_pripravi/ZObrMedresorsko_20160413.pdf.

- "Letno poročilo Ministrstva za obrambo za leto 2005.” Mors, 27 May 2014. Retrieved on 5 May 2016. http://www.mo.gov.si/fileadmin/mo.gov.si/pageuploads/pdf/ministrstvo/letno_porocilo_2005.pdf.

- "National Strategy for the Accession of the Republic of Slovenia to Nato." February 1998. Retrieved on 4 June 2016. http://nato.gov.si/slo/dokumenti/nacionalna-strategija.pdf.

- "Pomembnejši utrinki iz zgodovine Slovenske vojske od prevzema popolne suverenosti nad slovenskim ozemljem do danes - 20 let ponosni nase in v ponos Sloveniji." Retrieved on 7 June 2016. http://www.slovenskavojska.si/fileadmin/slovenska_vojska/pdf/sporocila/20let_zgod.pdf.

- Bebler, Anton. "Pot Slovenije v Nato = Slovenia's road to Nato." Bilten Slovenske vojske 11, No. 3 (November 2009): 105-16.

- Grizold, Anton. "Nejasen namen. Resoluciji o izhodiščih zasnove nacionalne varnosti Republike Slovenije na rob." Primorski dnevnik 49, No. 88, 1993.

- Grizold, Anton. "Obrambni sistem republike Slovenije. Stanje in perspektive nadaljnjega razvoja." In: Zbornik strokovno znanstvenih razprav, 161-81. Ljubljana: Ministry of the Interior of the Republic of Slovenia, December 1991.

- Grošelj, Klemen. Slovenija v svetu mirovnih operacij. Ljubljana, Založba FDV, 2007.

- Humar, David, Ivan Mikuž, Samo Zanoškar, Dean Groff and Leon Holc. "Integration of the Slovenian armed forces into NATO and EU military structures." Bilten Slovenske vojske 11, No. 2 (2009): 59-81.

- Janša, Janez. Okopi. Pot slovenske države 1991-1994. Ljubljana: Mladinska knjiga, 2014.

- Juvan, Jelena. "Mirovne operacije kot sredstvo zagotavljanja nacionalne varnosti?.” Defence Research Centre of the Faculty of Social Sciences of the University of Ljubljana. Retrieved on 2 July 2016. http://www.fvv.um.si/DV2010/zbornik/nacionalna_varnost/juvan_doc.pdf.

- Juvan, Jelena. "Slovenska vojska v mirovnih operacijah." In: In: Mirovne operacije in vloga Slovenije, ed. Ljubica Jelušič, 175-186. Ljubljana: Faculty of Social Sciences, 2005.

- Kladnik, Tomaž, ed. Vojaška obramba Slovenije 1990-1991. Ljubljana: Defensor, 2011.

- Kladnik, Tomaž. Slovenska vojska v službi domovine. Ljubljana: Defensor, 2006.

- Kranjc, Marijan. Slovenska vojaška inteligenca. Grosuplje: Grafis Trade, 2005.

- Kronologija včlanjevanja. "Slovenija in NATO: kronologija slovenskega vključevanja v NATO.” Retrieved on 25 June 2016. http://nato.gov.si/slo/slovenija-nato/kronologija/

45 "Protocol to the North Atlantic Treaty on the accession of the Republic of Slovenia," NATO Official text: Protocol to the North Atlantic Treaty on the accession of the Republic of Slovenia, 26-Mar.2003, available at: http://www.nato.int/cps/en/natohq/official_texts_20315.htm. 
- Lovšin, Andrej. “Obrambni sistem in kadri od leta 1991 do 2003, 2.” Slovenska vojska 12, No. 1, 16 January 2004.

- NATO, Official texts: Partnership for Peace Invitation Document, 10-11 January 1994. Retrieved on 7 October 2016. http://www.nato.int/cps/en/natohq/official_texts_24468.htm?mode=pressrelease.

- Official Gazette of the Republic of Slovenia. Ljubljana: Uradni list Republike Slovenije.

- Pirjevec, Jože. Jugoslovanske vojne: 1991-2001. Ljubljana: Cankarjeva založba, 2003.

- Prebilič, Vladimir and Jelena Juvan. "(Ne)obstoj slovenske vojaške identitete." Sodobni vojaški izzivi 14, No. 1 (2012): 55-67.

- Referendumski rezultati. "Poročilo o izidu glasovanja o izidu referenduma o pristopu Republike Slovenije k Organizaciji Severnoatlantske pogodbe (NATO), ki je bil 23. marca 2003." Retrieved on 8 October 2016. http://nato.gov.si/slo/slovenija-nato/referendum/rezultati/.

- Repe, Božo. Jutri je nov dan. Slovenci in razpad Jugoslavije. Ljubljana: Modrijan, 2002.

- Repe, Božo. Milan Kučan: prvi predsednik. Ljubljana: Modrijan, 2015.

- Repnik, Tomaž. “Odnos civilne družbe do Slovenske vojske v obdobju 1991-2006.” Diplomsko delo, Fakulteta za družbene vede, 2006.

- Slovenska vojska 12, No. 1, 1. "Prvih sto prostovoljcev."

- Slovenska vojska 12, No. 1, 16 January 2004. "Slovenci se počutimo varne."

- Špela Kranjc, "Članstvo v NATO. Študija primerov Slovenije in Estonije.” Diplomsko delo, Fakulteta za družbene vede, 2009.

- Šteiner, Alojz. Slovenska vojska med tranzicijo in transformacijo. Ljubljana: Slovenian Armed Forces, Military Schools Centre, 2015.

- Šurc, Matej and Blaž Zgaga. Vimenu države. Trilogija: book. 1: Odprodaja. Ljubljana: Sanje, 2011.

- Šurc, Matej and Blaž Zgaga. Vimenu države. Trilogija: book. 2: Preprodaja. Ljubljana: Sanje, 2011.

- Šurc, Matej. Prevarana Slovenija. Domoljubje, zapisano z ničlami. Ljubljana: Sanje, 2016.

- Žunec, Ozren. "Operacije Bljesak i Oluja." In: Rat u Hrvatskoj i Bosni i Hercegovini: 1991-1995, eds. Branka Magaš and Ivo Žanić, 93-110. Zagreb: Jesenski i Turk and Sarajevo: Dani, 1999.

Damijan Guštin

OBRAMBA REPUBLIKE SLOVENIJE 1991-2004:

OD SAMOSTOJNE V KOLEKTIVNO OBRAMBO

POVZETEK

Republika Slovenija je svoj obrambni sistem začela oblikovati še v okviru jugoslovanske federativne države in še pred tem, ko je najavila svojo osamosvojitev. Takoj po razglasitvi neodvisnosti je ta še ne docela vzpostavljen obrambni sistem uspešno prestal preizkušnjo, ko je bila 26. junija 1991 prisiljena v obrambo z oboroženo silo. Nadaljnji razvoj obrambno-varnostnega sistema Slovenije je po premirju in umiku sil JLA iz Slovenije potekal v mirnodobnih razmerah, čeprav je bila Slovenija še dolgo na robu bojujočega se zahodnobalkanskega prostora. Dogradnja obrambnega sistema je sledila edini možni smeri, obrambi s svojo oboroženo silo in z drugimi neoboroženimi strukturami, a željo, da bi se Slovenija vključila v kolektivno obrambo Severnoatlantskega pakta (Nato), saj je bila tipična majhna država, ki je svojo obrambo lahko zagotavljala le deloma. Razvoj je sledil dvema dolgima in obsežnima razvojnima procesoma: obrambno-varnostni sistem Slovenije je bilo treba dokončati in oblikovati glede na novo dejstvo neodvisne države; prevladujoča želja slovenske državne elite, da Slovenija preide na kolektivno obrambo, ki jo je predstavljala edina še delujoča vojaška zveza, Severnoatlantski pakt, pa ji je določila poglavitno smer, saj se je že od leta 1993 prizadevala za sprejem v NATO. Med tema procesoma pa so se vojske drugih evropskih držav temeljito spremenile; prilagodile so se spremenjenim varnostnim grožnjam, postale so manjše, fleksibilne, poklicne vojske, čemur se je poskušala prilagoditi tudi Slovenska vojska. Slovenski obrambni sistem se je v devetdesetih razvil tako po opremljenosti kot po organiziranosti, vendar pa so številne reforme obrambnega sistema in vojske sledila šele po letu 1997, ko Slovenija ni uspela s svojo prošnjo za sprejem v Natovo kolektivno obrambo, in zlasti po letu 1999, ko je Nato sprejel Akcijski načrt za članstvo, ki je vključeval tudi Slovenijo. Najbolj vidne reforme so 
zadevale njen obseg in strukturo. $V$ začetku novega tisočletja je začel slabeti varnostni in obrambni imperativ Slovenije, saj se je sosednji zahodnobalkanski prostor umiril. Posledica tega sta bili opuščanje skrbi za obrambo in zmanjšanje pomena varnosti in obrambe. Slovenija je od leta 2000 do končnega sprejetja v Nato leta 2004 izvedla drugi ciklus prilagajanja zahodnim armadam. Prilagajanje je zajelo tri pomembna področja, prilagoditev organizacije sil, ločitev med premakljivimi in nepremakljivimi silami; ločitev operativne ravni poveljevanja od strateške (poveljstvo sil na Vrhniki, generalštab v Ljubljani) in opustitev naborniškega sistema in uvedba poklicne vojske.

Leta 2002 je Slovenija končno dobila povabilo k pristopnim pogajanjem za članstvo v Natu. S tem so se začele hitre spremembe: zmanjšanje rezervne sestave na manj kot 50 odstotkov prejšnjega sestava, odpravljanje naborniškega sistema, odprava obveznega služenja vojaškega roka, ki je bilo izvedeno 2003, eno leto pred predvidenim rokom, in uvajanje poklicne vojske, snovanje sil, ki bi sodelovale v zavezniškem kontingentu. Delež izdatkov za obrambo se je po desetletju upada spet približal dvema odstotkoma BDP. Uvedena je bila zgolj poklicna vojska z okoli 7600 poklicnimi vojaki, podčastniki in častniki, ter dopolnilna pogodbena rezerva, ki pa je ostala maloštevilna.

Vzporedno s spremembami je referendum o vstopu v Nato s 66,08 odstotka glasovalcev za vstop dal politično-državni eliti dovolj veliko podporo za sklepne poteze vključevanja. Slovenija je 29. marca 2004 z ratifikacijo pristopnega sporazuma postala članica Nata in s tem dosegla zastavljeni cilj, prešla v kolektivno obrambo. 